\title{
HERPETOLOGICAL NOTES WITH NEW SPECIES FROII THE AMIERICAN AND BRITISH VIRGIN ISLANDS, 1936
}

\author{
Chapman Grant, U. S. Army, Retired.
}

Army duty in Puerto Rico during 1930-32 afforded the opportunity to collect intensively on nearly all the islands from Mona at the west to Anegada at the east. Only part of a day was available at St. Croix and several islets were missed which gave me a desire to return to complete the work. The collecting netted over 7,200 specimens including 17 new species and the rediscovery, reestablishment or adding to the fauna of several more which brought the total to 77. This collection was reported in the Journal of the Department of Agriculture of Puerto Rico beginning in the July, 1931, issue.

St. Croix lies to the south and is separated by a deep channel from the Puerto Rico-Virgin Island group which lie on a shallow bank. It seemed likely that the separation denoted a great lapse of time which would have made all of the species endemic, but Barbour listed several species as common to it and the adjacent bank islands including Puerto Rico. This seemed so unnatural to me that there remained a longing to explore the island more thoroughly. Mr. T. G. Plant of the American-Hawaiian Steamship Company offered the realization of this hope by kindly furnishing transportation on the S.S. "Willboro" from Los Angeles, whence we sailed February 18, 1936, arriving at Puerto Rico March 5. Captain George Grundy and his Officers made the trip a pleasure beyond its usual interest.

On the journey it was noted that the marine snake, Hydrus platurus (L) did not appear as far north as it was seen in September 1930. It seems possible that more data might show a migration.

In Puerto Rico the welcome of the Lighthouse Tender, "Acacia", was again accepted which evoked the memory of pleasant trips with Captain Manyon in 1930-32. On March 14 we landed for an hour at Las Mulas, Vieques. Here we found that Bufo marinus had been introduced since our visit in 1931. (Jour. Dept. Agri. Puerto Rico, 16(1) 37-39). The same day we landed at Culebrita where it had not rained for fourteen months. A. cristatellus was plentiful. Seven A. exsul and $31 \mathrm{~S}$. macrolepis were taken. A bottle was left which Mr. E. A. Murray of the "Acacia" mailed to me in Oc- 
tober. It contained $3 \mathrm{~A}$. exsul, $60 \mathrm{~S}$. macrolepis, $1 \mathrm{~T}$. platycephalus and 1 Mabuya sloanii. The last two are new records for this island. These 60 macrolepis added to those taken in 1931 total 91 specimens which do not include any of the red-headed S. danforthi which oecurs across the narrow channel on Culebra. It seems strange that the red-head form should occur on Culebra and the comparatively distant Anegada and not on Culebrita. In a previous paper, (Jour. Dept. Agri., Puerto Rico. XV. pp. 205-207) it was not realized that $S$. danforthi and $S$. macrolepis occur together on Culebra. They are easily distinguished by the speckled throat of macrolepis. The speckling starts at the chin and continues to the neck where it stops abruptly. Danforthi has a clear chin and throat and the male has a red head.

The next day, March 16, we landed at Buck Island, of St. Croix where two of the plentiful Anolis acutus were taken. During this visit and in 1932 the writer saw no other reptile on this good sized islet. We then sailed for Christiansted, St. Croix, where the hospitality of the "Acacia" was left behind to commence the intriguing problem of:

\section{The Herpetology of St. Crolx}

This expedition unfortunately coincided with a very severe drought. Ponds which no one remembered to have seen dry were expanses of eracked, baked earth. I was fortunate in meeting $\mathrm{Mr}$. Harry Beatty, who is an ornithologist and is now working with the Public-Health Service on filaria control. He was born on St. Croix some thirty years ago and is a field naturalist and an artist of ability. His life of close observation made protracted collecting on my part unnecessary as he personally conducted me all over the island and gave me full benefit of the experience of his observations on the island.

Practically all of the island is in one life zone. Rolling, brushcovered hills of moderate height, a moderate amount of cactus, intermittent streams with a few trees complete an uninteresting picture. It seemed unbelievable that such a large island could be as depauperate of species as is shown by Barbour's list, but results showed that even his scanty list included several species due probably to old errors in data. The fauna is really poorer than his list shows, as the following indicates: 


\section{Bufo marinus (L)}

Introduced from Puerto Rico in October 1934 at the Agricultural Experiment Station. It had spread 11/2 miles east and six miles west in 1936. Under date of October 24, 1936, Mr. Beatty writes: "B. marinus has become well dispersed."

\section{Eleutherodactylus lentus Cope}

This species was found under rocks at the few damp places and ponds persisting on the island. Specimens taken: 1 Anguilla; 7 Criqui stream, West End; 1 Good Hope Estate; 1 Experimental farm. These averaged much smaller than the St. Thomas specimens, but larger specimens may be available in the rainy season. If not, this is truly a pigmy race.

\section{Eleutherodactylus portoricensis? Schmidt}

Mr. Beatty writes, October 24: “A Puerto Rican liberated a number of Coqui here". This species cannot yet be included in the fauna.

\section{Leptodactylus albilabris (Gunther)}

All specimens were very much smaller than those seen elsewhere. Otherwise they appear to be identical with those from St. Thomas, St. John and Tortola, which in turn are smaller, darker and less attractive than the occasional red or green marked specimens found in Puerto Rico. Specimens taken: 1 Criqui stream, West End; 6 Experimental farm; 14 Good Hope Estate. Nests were found at West End under rocks above the water line. I have never seen nests connecting with the water and it is not clear how the young get to their element.

\section{Rana pipiens Schreber}

Mr. Beatty writes Oct. 24: "Dr. Augustine of Harvard liberated 12 adults at Criqui dam'. This species cannot yet be included in the fauna.

\section{Hemidactylus mabouia (Moreau de Jonnes)}

This species appeared very scarce in the dry season. Mr. Beatty had two preserved specimens. Specimens taken: 1 in the public library at Christiansted; another was seen at the old fort. $\mathrm{He}$ writes that he has captured several at the fort and has since (Jan. '37) sent 7 more, showing that the scarcity was due to the drought as he caught them all at the old fort at night. 


\section{Thecadactylus rapicaudus (Houthuyn)}

Strangely enough Barbour does not list this species from St. Croix, altho both Stejneger and Schmidt do. Mr. Beatty gave me an alcoholic specimen and a second was given by employees of a sugar central. Mr. Beatty took me to a well where he had caught the first specimen and there we captured a second fine specimen hiding between the stones near the top. A fourth was seen by flashlight in a tamarind tree, but not secured. The natives are all familiar with these "wood slaves" and say: "They bawl like a fowl in the tamarind trees at night". The three were compared with 54 specimens in the American Museum. It was found that the St. Croix form has a row of large scales next above the upper labials, whereas all but 8 of those in the museum have the fine granules next to the upper labials. The 8 which most nearly approach the St. Croix specimens are all from Dominica. This may be another interesting "leapfrogging" of characters or the St. Croix stock may have come from Dominica. Another specimen taken in trees at night at Mount Victory Estate was received from Mr. Beatty, Jan., 1937. It agrees in squamation with the above.

\section{Sphaerodactylus macrolepis Gunther}

Distributed throughout the island in suitable localities. Specimens taken: 17 Good Hope; 16 Criqui stream, West End; 1 Protestant key; 4 Tagus point, East End; 8 West End; 11 gift of Mr. Beatty from West End. In Jan., 1937, Mr. Beatty sent 11 more from East End. It was described by Gunther (1859, Ann. Mag. Nat. Hist., (3), Vol. IV, p. 215). Excerpts from the original description follow: "Body surrounded by about forty longitudinal series of scales of rather large size. . . those of the back keeled, of the belly smooth. Trunk and tail uniform blackish brown, in younger individuals some scales with blackish tips; head grayish brown, marbled with black; jaws and throat striolated with blackish. . . . The scales of the throat are small, those of the breast and of the extremities keeled. . . . The tail is covered with smooth scales. . . . the belly is uniform dirty white, and the tail minutely dotted with blackish. Two specimens were in the collection."

Since Gunther's time various collectors have taken similar lizards from islands as far away as Mona and lumped them with this species because of a general superficial similarity. They probably believed that there was considerable individual variation. Consequently any little gecko with a similar pattern and scales of about the size borne 
mainder of the underside being usually clear or very lightly speckled or clouded. Fig $2 \mathrm{~A}$ and B. The female is similar to the female on St. Croix except that the occipital black spot is more definite and the central part of the throat and the whole underside is much clearer white. Fig. 3 A and B. S. danforthi Grant, Fig. $2 \mathrm{C}$ and D, is found on Culebra and strange to say, also on Anegada. Fig. 4. An impossible distribution perhaps but I am unable to separate the forms.

This species is best known in life by the red heads of the males. Preserved specimens can be distinguished by: males lack any head pattern except a faint occipital dark spot. The throat does not have the black and white spots. I cannot distinguish the females from the female macrolepis. Originally I described danforthi as having a dichromatic male. I would now modify this assumption by saying that the redheads were the adults and the spotted heads were immatures, except for the fact that I have not seen an intermediate on Culebra and, still more convincing, the speckled throated macrolepis does not occur on Anegada and the redhead form does not occur with macrolepsis on any other of the Virgin Islands. There is a puzzling form on Vieques which may be distinct or it may be a hybridization between danfortti $i$ and macrolepis, but no intermediates have been found on other islands.

While collecting on Culebra in 1932 one female Sphaerodactyl was taken which made me doubt that the male danforthi was dichromatic. I therefore went on record that the redhead form was the type of danforthi. A constant character of the danforthi-macrolepis group is that the chin and throat of the females are never conspicuously marked with black and white, but are faintly streaked with dull brown. This one female however, had conspicuous black and white throat markings and I thought it possible that she might be the only female danforthi taken. This specimen is larger than any other specimen taken on Culebra and the scales are larger and coarser, being 18 in length and 35 around the body. More of this material may prove interesting. Fig. $3 \mathrm{C}$ and D. To return to St. Croix :

\section{Sphaerodactylus beattyi sp. nov.}

Type: Adult female, 80567, U.M.M.Z. Collector, Chapman Grant, May 17, 1936.

Habitat: Eastern end of St. Croix.

Diagnosis: An extremely slender Sphaerodactyl with finer scales than any heretofore known from this area, and a distinct change of pattern during growth. 
by macrolepis was considered to be of that species. My previous reports include this error. I first detected the lumping in the case of S. grandisquamis (Jour. Dept. Agri. P. R., Jan., 1932, pp. 43-45.)

In the light of more thorough collecting and the discovery of an easy way to determine the sexes ${ }^{1}$ it has been found that several species have a marked sexual dichromatism and that there is not a very great individual variation in color or pattern. As a consequence, after determining the sexes it is frequently possible to allocate the specimen to a certain island purely from pattern.

The size of dorsal scales varies somewhat among the species, but Barbour's unit of measurement is to take the number of dorsals contained in the distance of snout tip to center of eye. It is believed that this measurement is too short with consequent possibility for inaccuracies. We recommend the count of a dorsal row from a point opposite the middle insertion of the front legs to a point opposite the middle of the insertion of the hind legs. This gives a range of between 18 to 28 scales for all but one species of this region.

Gunther's description of macrolepis is sufficiently exact to differentiate it from the other species on St. Croix. Some further characters of this species might be mentioned. The basic target pattern on the head of the male is so much broken up that the head appears to be marbled with irregular, fine broken designs of dark on gray. There is always a light stripe between the eyes. The scapular mask pattern is missing or very small; the rest of the back is an even gray-brown or contains occasional dark scales which give a dotted appearance. The chin is evenly mottled, black and white. This pattern does not stop short at the neck, but extends onto the chest and also shows occasional dark spots all over the belly and underside of legs and tail. Fig $1 \mathrm{~A}$ and $1 \mathrm{D}$.

The female is much like the females of adjoining islands which represent this species, but like her mate, her underside is spotted with brown. The throat does not have the even, black and white dotted pattern, but bears ill defined brown streaks which give it a dirty appearance. Fig. $1 \mathrm{~B}$ and 1 C. Macrolepis varies from island to island and will doubtless be broken down into more species or subspecies as material accumulates. On Culebra, where it occurs with danforthi, the head pattern of the male is of mottled black and white with a black occipital spot clearly indicating the target pattern of the female. Ventrally, the sharply contrasting black and white throat pattern of the male stops abruptly at the neck, the re-

\footnotetext{
${ }^{1}$ Grant, The Sphaerodactyls of Puerto Rico, Culebra and Mona Islands. Jour. Dept. Agri., P. R. XV. No. 3. July, 1931, p. 199, Pl. XX.
} 
Description of type: Adult female: about 46 dorsal scales in line between a point opposite insertion of front and hind legs and about 56 rows around the body. This is about double the number on other species in this area. Color above, dark gray without trace of scapular pattern; occasional clark scales on back and tail. An indistinct dark spot at occiput; a dark line centrally from snout to occiput. Note that this is the only species in the area with a dark stripe between the eyes. On other species the line divides before reaching the orbits, leaving a light line between the eyes. Underside clear light; indication of light " $\mathrm{Y}$ " on the sacrum. Fig. 5 $A$ and $B$.

Variation: The male is marked identically like the female and can be told only by the escutcheon. Immature, but full grown specimens of both sexes have an elaborate pattern. A dark median line from snout to just beyond the occiput. Another dark line from snout over eye to above ear. Another dank stripe along side of face. Throat clear or mottled or sometimes clouded with minute specks which may extend along the belly. Remainder of back marbled more or less conspicuously with dark brown and gray according to age. A distinct and specific mark is a light " $\mathrm{Y}$ ", the branches of which start on the sacrum and the stem runs onto the tail. This "Y" does not show well on the type which has a regenerated tail, but appears clearly on all the other specimens. Fig. $5 \mathrm{C}$ and D. This and the central head stripe are apparently the only marks which do not disappear with age. Underside as in adults. My original collection from St. Croix contained the one adult and four immatures. Fig. $5 \mathrm{D}$.

Through the kindness of $\mathrm{Mr}$. Shreve of the Museum of Comparative Zoology at IIarvard the type was compared with a cotype of S. vincenti and found to have a less granular mid-dorsal area and different scutellation round the rostral and supranasal region and also to differ in coloration.

Twenty-six specimens examined.

Named in honor of Harry L. Beatty.

\section{Iguana i. iguana (L)}

Neither Barbour, Stejneger nor Schmidt reported this species, but Dunn reports it in Copeia 1934 No. 1. p. 1. They are known by the rural inhabitants who say they used to be plentiful in places. Mr. Beatty and $\mathrm{Mr}$. Robert Nichols of the Agricultural Experiment Sta- 
tion of St. Thomas killed and mounted one specimen from Tagus Point, East End which the writer saw and positively identified. Now they occur only at Tagus point in trees surrounding brackish lagoons in which they take refuge. I saw many of their characteristic foot and tail tracks on the beach sand, but did not see a specimen.

\section{Anolis acutus Hallowell}

This is the most abundant life on the island. Mr. Beatty reports taking eleven from the stomach of one mongoose. The species occurs everywhere on St. Croix, Buck Island and Protestant key. Specimens taken, 2 Buck Island, 1 Good Hope, 4 Experiment Station. A large series was taken in 1932. In January $1937 \mathrm{Mr}$. Beatty sent me 3 specimens from Green Cay near the harbor of Christiansted. This species closely resembles $A$. cristatellus in the field. Schmidt 1928 p. 26 considers it directly related to $A$. poncensis and Barbour, 1930 considers it close to $A$. krugi. The throat fan is very distinctive but unfortunately shrivels and loses color in alcohol.

The following Anoles do not occur on St. Croix: Anolis cristatellus (D. \& B.), listed by Schmidt p. 151. Anolis newtoni Gunther, type locality "St. Croix" of which Barbour states: "I have never seen this species and know nothing about it." Anolis pulchellus D. \& B. is listed by Barbour and Schmidt. Mr. Beatty has never seen it on St. Croix. Familiarity with the habits of this form and $A$. poncensis on Puerto Rico and a careful search leads me to believe that specimens labelled "St. Croix" are in error.

\section{The Rediseovery of Ameiva polops Cope}

Ameiva exsul Schmidt, 1928. N. Y. Acad. Sci. Vol. X. Pt. 1. Barbour, 1930 and 1935 Zoologica, Vols. IX p. 102 and XIX. p. 126. "I have always doubted the St. Croix record."

Ameiva rïsei Reinhardt and Lutken, 1862. Vidensk. Meddel. pp. 232-233. "A. riisei is sent in from St. Thomas, St. Jan and Water Island, Vieques and Porto Rico."

Ameiva orstedi Bocourt, 1870. Recherches Zoo. Cent. Am. \& Mex.

Pl. XX. figs. 4 and $4 a$, "St. Thomas" are clearly $A$. polops, the locality being in error. Ameiva plei Cope, 1862, Proc. Phila. Acad. p. 65. Ameiva polops Cope, 1862, Proc. Acad. Phila. p. 66. Reinhardt and Lutken, 1862 Vidensk. Meddel. pp. 232-233. Cat. of Lizards, Br. Mus. 1885, Vol. II p. 35. Stejneger, 1904, U.S.N.M. No. 129 p. 564. Barbour and Noble, 1915, Bul. M. C. Z., LIX. No. 6. c: 
Schmidt, 1928 N. Y. Acad. Sci. Vol. X. p. 153 "Known only from the type from St. Croix." Barbour, 1930 and 1935 Zoologica Vols. IX. p. 102 and XIX p. 125. "Extinct, but very few specimens have been preserved."

Intensive field work with A. exsul, A. wetmorei and their allies gives one an understanding of the confusion quoted above. $A$. exsul varies so much with age and locality that it was natural for the pioneers to make separate species of the different pattern stages whether due to age or locality. Mr. Beatty thought that the "ground lizard" which used to occur all over the island was $A$ exsul since A. polops was supposed to be extinct. He reported it as still extant at East End, in some empty city lots facing Christiansted harbor and on Protestant key. This key comprises about three acres suitable for $A$. polops and there is much building going on with a view to making a park out of the key The completion of this project or the introduction of a cat or mongoose would probably exterminate this interesting lizard on this key. We were unable to find any specimens except on Protestant Key where we took eight of what we estimate to be about 35 specimens. They are very wild. Mr. Beatty made an accurate color sketch of a freshly killed specimen which unfortunately cannot be reproduced for this article. There may be other specimens in museums labelled $A$. exsul ete. In a late letter dated January 15, $1937 \mathrm{Mr}$. Beatty says: "On my first visit to Green Cay in 1936 I did not see a single Ameiva during an entire morning's search. On my second visit, recently, I observed many scurrying about the beach, a large number of these being young. I dissected a few and found that they were feeding on the species of semiaquatic amphipods, very abundant among beached seaweed. Ameiva seems to have disappeared entirely from the mainland where formerly they were abundant in certain localities."

Color notes from a freshly killed specimen are given: Head, olive, a wide light olive stripe from nape to sacrum; laterally a faint light yellow line which disappears at midboảy; laterally to these, a black or dark brown stripe onethird width of central stripe; laterally to these, a narrow yellow stripe from top of ear to thigh; a dark reddish brown stripe along side of body below last mentioned stripe from behind ear (width of ear) including top of thigh and extending onto tail where it disappears one third way down; below this is a narrow gray stripe from under ear to shoulder, beyond which this stripe becomes bright blue with speckled edges to groin. It misses the front of the thigh, but appears from knee to foot and behind thigh to little toe and down tail for onethird its length where it disappears. Below this stripe is a black band with uneven edges from axilla to groin and extending half the length of the tail where it disappears. Underside; chin and chest deep salmon, two and a half 
rows of ventral plates from center line a dirty light blue; two and a half rows lateral to these are bright peacock blue. Tail; sides and bottom distinctly ringed along central three quarters of its length. Rings obscure along top of tail. Side of head, snout and labials, salmen; a white ring around ear.

The largest male measured; Total length $235 \mathrm{~mm}$; snout to vent, 64; snout to center of ear, 19; width of head at ears, 10; foreleg from axilla, 25; hindleg from groin, 50; tail, 171.

\section{Amphisbuena fenestrata Cope}

Listed by Barbour and Schmidt. This species has never been seen by Mr. Beatty who writes on October 24, 1936 and again on January 15, 1937 that the drought is over and that he and Dr. Seamen have watched the plowing by the Virgin Island Sugar Cane Co. of various overgrown fields without results. I turned many logs and rocks and watched plowing during my stay also without results, but the drought might have accounted for that. It is recommended that this species be dropped from the fauna of St. Croix. If an Amphisbaenan is ever discovered it will doubtless prove to be endemic. I believe its absence may be parallel to its absence on Jamaica.

\section{Mabuya sp.}

Barbour lists M. sloanii Daudin in 1930. In 1935 he gives $M$. mabouia as occurring "through the West Indies". Schmidt lists M. sloanii from St. Croix. Mr. Beatty has never seen a skink on St. Croix. If one did exist there it is probably now extinct. The evidence seems insufficient to retain this species in the fauna.

\section{Typhlops richardii D. \& B.}

Barbour 1919 lists T. lumbricalis as occurring; in 1930 he mentions the genus as occurring, but in 1935 omits it. Schmidt lists $T$. richardii. Stejneger omits the genus.

Specimens secured: 1 Little Le Grange and 1 Anguilla, gift of Mr. Beatty; 2 West End, gift of Mr. Nichols of St. Croix; 1, Mr. Beatty, no data.

Mr. Beatty writes on October 24, 1936: "Typhlops is not uncommon at present, but certainly is very restricted in range, being confined to certain slopes in sections of the northwestern hilly portions of the island." Mrs. Gaige writes that these specimens cannot be separated from $T$. richardii. 


\section{Alsophis sanctae-crucis Cope}

Mr. Beatty, has not seen a specimen since he was a child, but his father and all the older generation remember them as having been plentiful. They have probably been exterminated by the mongoose here and on Buck island. It may still occur on Protestant key, but we searehed for it at the optimum time, 8-10 A. M. on two occasions without result.

To recapitulate: We have only eight species which we may feel reasonably sure were pre-columbian:

Eleutherodactylus lentus Cope

Leptodactylus albilabris (Gunther)

Sphaerodactylus macrolepis Gunther

Sphaerodactylus beattyi sp. nov.

Anolis acutus Hallowell.

Ameiva polops Cope

Typhlops richardii D. \& B.

Alsophis sanctae-crucis Cope

Of these 5 are endemic with the possible addition of the two frogs which may be a distinet pigmy race.

Iguana $i$. ignana may have been introduced by the Caribs for food.

Hemidactylus mabouia and Thecadactylus rapicandus may have been introduced by sailing ships in early days.

Bufo marimus is of recent introduction, but is well established. Other species have been so recently introduced that their establishment is questionable.

No St. Croix species is identical to the Puerto Rican fauna. $E$. Albilabris is much closer to the small, dark Virgin Island strain than to the larger, more vividly colored Puerto Rican form. St. Croix was apparently connected to the other Virgin Islands long after they were separated from Puerto Rico.

The next stop was St. Thomas whence two trips were made to Tortola and a few hours spent on St. John. While at St. Thomas my stay was made delightful by the kindness of Captain and Mrs. T. C. Rose of the Public Health Service. Captain Rose made the sturdy "Q-20" available for several trips to outlying islands and Mr. Robert Nichols of the Agricultural Experimental Station took me on several trips over the island in his car and accompanied me in several boat trips in the extraordinary little built-up dug-out of the "Cha-cha" fisherman, Joe Olivo. Joe's enthusiasm in collecting was a constant source of pleasure as he would spy the "next qual- 
514 THE JOURNAL OF AGRICULTURE OF THE UNIVERSITY OF P. $R$.

ity", meaning another species, on the various islets we visited. His pronunciation of the constant protest against the dry weather was inimitable, "Oh, very druoy."

First we will list the collecting done on and about St. Thomas.

ST. THOMAS

\section{Eleutherodactylus lentus Cope}

Thirteen from a cistern at Villa Olga near sea level. They are much more yellow and larger than the specimens from St. Croix. Color note from live specimens: Sides and back of thighs dark brown and white marbled, remainder dark brown and tan in large. specimens and dark brown and olive green in smaller specimens. Belly white, chin light yellow; under rear of thighs red. Three from a cistern at top of west end of island, elevation about 1,000 feet.

\section{E. antillensis R. \& L.}

A number taken from banana sheaths at top west of island.

\section{E. cochranae Grant}

About 52 of this and the last preceding taken together.

\section{Leptodactylus albilabris Gunther}

Three from the Ag. Exp. Station and a number from the top west of the island. This was the only damp spot we could find in the higher parts of the island.

\section{Hemidactylus mabouia M de J.}

Three from the quarantine station. This species is common on the island.

\section{Thecadactylus rapicaudus (Houttuyn)}

Mentioned by Schmidt, but I find no trace or other record. It should be dropped from the fauna until rediscovered.

\section{Sphaerodactylus macrolepis Gunther}

Twenty-two specimens taken at quarantine station, Villa Olga, Ag. Exp. Station and top west of island. Common in suitable places. 


\section{Iguana $i$. iguana L}

Seen mostly in eity gardens in the shrubbery and near "Bluebeard's Castle". Horribly stuffed specimens are hawked by the natives.

$$
\text { Anolis cristatellus D. \& B. }
$$

Ubiquitous. Exceeds all other species combined.

$$
\text { A. stratulus Cope }
$$

Collected here before, but none seen in this drought.

$$
\text { A. pulchellus D. \& B. }
$$

Same as the last.

\section{Ameiva exsul Cope}

Very numerous around Villa Olga where they live in the crab holes coming out in mid morning and mid afternoon. Two taken. They occur throughout the town, at the quarantine station and more sparingly throughout the brush.

\section{Amphisbaena fenestrata Cope}

Neither Mr. Nichols nor I have seen this species from St. Thomas.

\section{Mabuya sloanii Daudin}

Probably extinct on Șt. Thomas proper, or very rare.

\section{Typhlops richardii D. \& B.}

Mr. Robert Nichols presented eight which had been collected at the Agricultural Experiment Station during the last year. I found one specimen under a rock at the top of the west end of the island. It was very small and was aestivating in a hole similar to those used by aestivating Lumbricus and may well have been one whence the rightful owners had been eaten. Of this specimen Mrs. Gaige says: "It has only 20 rows and the dorsal count is somewhat low for richardii and it is short bodied for that species.

\section{Dromicus exiguus Cope}

Three from the Experiment Station presented by Mr. Nichols. 


\section{Alsopliis antillensis Schlege]}

Probably long extinct. Neither Mr. Niehols nor I have heard any recent reports of them.

\section{Testudo tabulata Walbaum}

A few specimens are kept in gardens or cemeteries as pets.

There follow records from the islets adjacent to St. Thomas: Buck Island (or Capella Islands as it appears on some charts. Capella is the diminutive for she-goat.)

Alsoplis and Mabnya are the first reptiles to disappear from any island, whereas Ameiva is one of the most persistent. It occurs on every liey or islet where there is any suitable ground or cover. Nevertheless Ameiva does not exist on these large, suitable islands and the two most likely to disappear are to be found; the skink in profusion and the snake occasionally. I have visited the islands repeatedly and have taken men and boys along for a thorough search in the optimum part of the day without finding trace of Ameiva.

A new record for this island was $S$. macrolepis of which four specimens were taken and $A$. cristatellus was very numerous. Three M. alvanii were taken.

The Alsophis on this island varies more from antillensis than does variegatus from portoricensis. Three specimens were taken on the northern of the two islands, being the island which bears the lighthouse.

Alsophis nicholsi sp. nov.

Holotype: No. 80648, Museum of Zoology, University of Michigan; March 15, 1936. Collector, Chapman Grant.

Habitat: Known only from the northern of the twin islands known as Buck Island or Capella Islands, off the port of St. Thomas, Virgin Islands.

Diagnosis: A pale form with the squamation of antillensis but the pattern of portoricensis, namely differing from typical antillensis in that the lateral stripe on scale rows four and five is visible only on the neck, where it is very faintly indieated, the broad dark dorsal band is likewise faint and is evidenced only by a gradual darkening of the more dorsal scales and the pattern on the eighth row is missing. The chin, throat and fore part of the body are immaculate and lack any traces of the characteristic mottling or spotting.

Description of Type: Head seutellation normal and the same as that of typical antillensis, as are other structural features. Ventrals 185, tail broken. In life the dorsal ground color is pale olive green, which fades to pale brown in aleohol. This color is light laterally, but becomes more intense dorsally. Each scale with a diffused darker margin. On the neck there is evidence of 
the characteristic dark lateral band on seale rows four and five, but the characteristic marks which occur on the eighth row of antillensis are missing. The upper surface of the head is colored like the dorsum, each scale partially bordered with dark brown; the side of the head is not differentiated in color. A very narrow dark line demarks the sutures between the supralabials and the seales lying above them. The chin is almost immaculate white, with only a very few light brown mottlings. The anterior part of the belly is immaculate white; the posterior part and ventral side of the tail is white, slightly dotted with brown.

Variation: The two paratypes, No. 80640, March 5, 1936 and 80641, April 20, 1936 are essentially the same as the holotype. The ventrals are 181 and 182 ; the tails of both are broken; one specimen has a broken, posterior brown border on the posterior ventral and subcaudal shiclds. The snakes taken on surrounding islands are typical antillensis.

Di. Stuart kindly furnished most of the above description since the specimens are at Ann Arbor and this is written in California.

Named in honor of $\mathrm{Mr}$. Robert A. Nichols of the Agricultural Experiment Station, St. Thomas, Virgin Islands.

Hassel island forms the west side of St. Thomas harbor and is the type locality of $E$. cochrance. A very much spotted $A$. exsul was taken; a dead Iguana $i$. $i$. was seen in a disused rain eatchment basin; $A$. cristatellus was abundant; no $E$. cochrance were seen probably on account of the drought, neither were any salentia seen on any of the other islets.

Water island is large and lies west of Hassel, near the "mainland" of St. Thomas and has no mongoose. One Iguana $i$. $i$. was shot as it jumped off a rock and started to swim into a shallow lagoon. The legs are not used in swimming, but locomotion is accomplished by a sinuous movement of body and tail. They are adept diver's, being able to stay under water a considerable time. This speeimen contained 22 eggs. Several others were seen in this same lagoon which was the only one left which contained water. Normally there are several filled with brackish water. Two Alsophis antillonsis were taken. They are more plentiful here than on any island visited. A. cristatellus, A. stratulus, A. pulchellus and $A$. exsul were numerous. A colored charcoal burner had just captured a small Testudo tabulata which is found feral on this island.

Little Saba Island lies further west, about half way to the western tip of St. Thomas. Two new records were made for the island; an Alsophis antillensis and a Mabuya sloanii were taken and mother skink was seen. A. cristatellus, A. stratulus, A. exsul and S. macrolepis were seen. This is a steep little islet, covered with thick grass, 
a few cactus and a patch of small trees and a nice little lagoon. Adjacent are two keys known as Turtle-dove and Flat Keys, but they were not visited.

Savana Island lies near the west end of St. Thomas. It is a very steep, rocky islet covered with thatch palms; has a few goats that have eaten off all the grass, but there are no mongoose. We took a $S$. macrolepis, 2 very large $A$. exsul and 2 Alsophis antillensis. A. cristatellus was common, A. stratulus uncommon.

Salt Key lies off the west end of St. Thomas. A good sized islet, having diversified terrain, a lagoon, dry at this time and with all the appearances of good collecting, but $A$. cristatellus and $A$. exsul were the only species seen. West Key, lying between this and the west tip of St. Thomas was not visited.

Dutchman's Cap is a steep rock bearing a few cactus and stunted trees and its ubiquitous goats. A. cristatellus and $A$. exsul were the only species seen.

Cockroach Island is a steep rock furnishing seabirds with a rookery. A little dirt and coarse grass and goats complete the picture. The collecting results were better however, as the islet produced $3 \mathrm{~S}$. macrolepis which did not look at all typical, $3 \mathrm{~A}$. cristatellus and a dead Alsophis antillensis which must have been killed by the sea birds or the goats. There were no Ameivas.

Off the north shore of St. Thomas lie Inner and Outer Brass Islands. They are very rough, covered with small trees and goats and sea birds nest on the outer one. They produced only $A$. cristatellus and A. exsul. Pelican Key, Hans Lolick and Little Hans Lolick Islands, Grass Key and Thatch Key off the northeast of St. Thomas were not visited. The islands off the east end were reported on in 1932. They produced only S. macrolepis, A. cristatellus, A. pulchellus, A. stratulus, A. exsul and Alsophis antillensis. Frenchman's Cap, south of St. Thomas was not visited.

A few hours were spent at Cruz Bay, St. John where A. exsul, A. stratulus and A. cristatellus were taken and Hemidactylus mabouia was seen. At Cinnamon Bay 11 S. macrolepis and 2 Eleutherodactylus portoricensis were taken. The frog was not found at Cruz Bay in 1932, but was reported as heard from the general locality of Cinnamon Bay. (Jour. Dept. Agri., P. R., XVI. p. 340.)

Three visits of several days each were made to Tortola in the hope of securing more specimens of Epicrates granti, but this island was: also in the grip of the drought.

The following specimens were taken on Tortola: $2 L$. albilabris, one having the burrowing snout developed; $50 \mathrm{E}$. antillensis, mostly 
of a uniform gray; $94 \mathrm{E}$. portoricensis, all having considerable red on the legs and even on the snout which was never noted on Puerto Rico. They differed also in being uniform in size and without pattern; 3 Hemidactylus mabouia from the east end of the island. These were found in a hut where a small necked bottle was found to have received 14 nearly spherical eggs and some hatehed shells similar to $S$ phacrodactyl eggs, but much larger. They measured $8.5 \times 10$, $9 \times 10$ and $10 \times 10 \mathrm{~mm}$. Some latehed on the way to New York and they and the remaining eggs were given to Dr. Noble's Experimental Biological Department. The fact that these eggs do not adhere to the surface where the female deposits them lessens the possibility of fortuitous distribution in $\log \mathrm{s}$ and other freight. $125 \mathrm{~S}$. macrolepis were taken while $A$. cristatellus, $A$. pulchellus and $A$. stratulus were plentiful and a few were taken. $A$. exsul is fairly abundant. One Amphisbaence fenestrata and 6 Dromicus exigurs were also taken.

\section{The IsLaNDS AND KEYS ADJACENT to TORTOLA}

Peter Island produced 4. $H$. mabouia, one of which contained eggs and several were infested with tiny red mites; S. macrolcpis, $A$. pulchellus, $A$. cristatellus and $A$. exsul were taken as was one speeimen of Alsophis antillensis. Dead Man's Chest is a tiny island coritaining eactus, trees, grass, an old ruin and goats, but should produce a good assortment. However $A$. cristatellus and $A$. exsul were the only species found. Beef Island is large and separated from Tortola by a narrow channel. It doubtless hides a respectallye list, but produced only A. cristatellus, A. stratulus and A. exsul. Cooper Island showed only the two standbys. Salt Island gave $2 H$. mabouia besides the two ubiquitous species. In 1932 I took Alsophis antillensis and Mabuya sp. on Salt Island.

Virgin Gorda is large enough to be treated separately if one might collect there in moist weather. Two trips to the island showed very good results considering the drought. One Bufo turpis Barbour was taken. This is a very different form from the equally rare $B$. lemur from Puerto Rico. Besides this the following were taken: 38 S. macrolepis, 8 A. cristatellus, very common, 8 A. pulchellus, $14 \mathrm{~A}$. exsul, 8 Mabuya sloanii and 6 Alsophis antillensis.

\section{The Herperology of Anegada}

Anegada is unique in structure among the islands of the Puerto Rico-Virgni Island group. Long before coming in sight of land, 
the gradually sloping white bottom is visible. Small sailboats have to anchor half a mile off shore, row boats stop 200 yards from shore whence the visitor wades. The island is perfectly flat, shaped somewhat like Cuba, covered with sand or a little soil over part of the pavement-like limestone. Small thorny growth sends its roots laterally in search of holes down which they disappear like fleeing serpents. The holes are of various sizes and some as smooth and round as if bored by an augur. The island was parched at the time of my visit.

\section{Leptodactylus albilabris Gunther}

This species is listed, but it was not found in 1932 or on this trip. The natives speak of a "crapeaud" showing that it or some other frog or toad appears during damp weather.

\section{Sphaerodactylus danforthi Grant}

Abundant under dead leaves. Some males had lemon-yellow heads, others the typical orange-red heads. Thirty-nine specimens were taken.

\section{A. cristatellus and A. pulchellus}

The former abundant. The latter less so.

\section{Cyclura pinguis Barbour}

Two more specimens were taken one a yery large male. The stomach contained whole sea-grape leaves, whole Opuntia fruit and whole wild "nutmegs". Some of the natives keep dogs to kill iguanas with which to feed the dogs. These free ranging dogs are the only menace of extinetion which is imminent. Illustrations and color notes on this species appear in the Jour. Dept. Agri., P. R. XVI p. 342, 1932.

\section{Ameiva exsul Cope}

Fairly abundant. Called ground lizard.

\section{Mabuya sloanii Daudin}

Forty specimens were taken which appeared to have a constant difference in size and color from those on other islands. Mrs. Gaige writes: "The two differences you note-color and size, do seem constant in your series, but I cannot find any other differences." These specimens average $10 \mathrm{~mm}$. shorter and lack the dorsal tri-marked scales so typical of the species on other islands. 
I questioned the turtlers on this and other islands closely, both on this trip and in 1930-32, with entirely negative reports on $\mathrm{Ca}$ retta kempii. C. caretta is well known as are also the green and hawksbill turtles of course.

\section{Dromicus anegadae (Barbour)}

Two small specimens were taken. One appeared to have swallowed some very large object, but it was found to contain three very large eggs in an oviduct. Mrs. Gaige kindly examined these two specimens and wrote under date of March 3, 1737: "I find the two specimens appear to be identical in scutellation and color, except; that one specimen has two large scale pits and the other has only one small, obscure one. This is the only difference between Alsophis and Dromicus as at present recognized." Thus it appears that Anegada may be a point of intergradation between these two genera as at present recognized.

On my return trip, while visiting near Río Piedras, Puerto Ricn I saw a large Rana catesbeiana crushed in the road. In 1932 I had heard of its prior introduction, but could not learn any dates. The importation was probably unofficial.

While in New York City, Mr. Carl F. Kauffeld of the American Museum, kindly allowed me to compare their fine series of Hemidactylus mabouia and $H$. brooki from Africa, whence the West Indian specimens are supposed to have come in slave ships, with my specimens and others from the New World. Their series of 71 specimens of $H$. mabouia from Nyassaland and 77 from the Belgian Congo was compared to New World specimens with the result that the Congo and New World forms are found to be alike, but the Nyassaland specimens are distinct as the accompanying table shows.

HEMIDACTYLUS MABOUIA (M de J)

\begin{tabular}{|c|c|c|}
\hline$=$ & New World and Congo & Nyassaland \\
\hline Length of adults, snout to vent.............. & $64 \mathrm{~mm} . \ldots \ldots \ldots \ldots \ldots$ & $80 \mathrm{~mm}$ \\
\hline Femoral pores of males...................... & $16-17 \ldots \ldots \ldots \ldots \ldots \ldots \ldots$ & 25 \\
\hline Femoral pores interrupted at midline........ & No..................... & By one scale \\
\hline 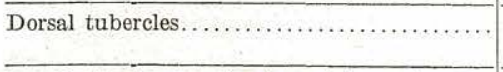 & $\begin{array}{l}\text { Strongly keeled, longer } \\
\text { than wide }\end{array}$ & $\begin{array}{l}\text { Not keeled, wider than } \\
\text { long or circular }\end{array}$ \\
\hline Longitudinal rows of spines at base of tail... & $\begin{array}{l}6 \text { strong rows of heavy } \\
\text { spines }\end{array}$ & $\begin{array}{l}4 \text { (rarely } 6 \text { ) weak rows } \\
\text { of short spines }\end{array}$ \\
\hline
\end{tabular}

\section{Hemidactylus brooki Gray}

This species is found only on Puerto Rico proper of the Puerto Rico-Virgin Island area. It was probably not introduced from the Congo by slavers as the following table shows. 


\begin{tabular}{|c|c|c|}
\hline 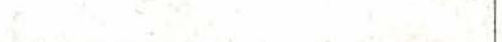 & Puerto Rico & Congo \\
\hline Femoral pores interrupted at midline by.... & One scale................ & 3 to 5 scales \\
\hline 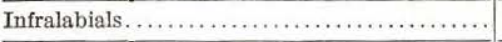 & $9 \ldots \ldots \ldots \ldots \ldots \ldots \ldots \ldots \ldots \ldots \ldots$ & 7. \\
\hline Mental wider than rostral.................... & No..................... & Yes \\
\hline Spines at sacral region and at base of tail... & Shorter................... & $\begin{array}{l}\text { Longer, heavier, thick } \\
\text { set }\end{array}$ \\
\hline
\end{tabular}

The above table is derived from the 32 males of a large series from the Congo. It appears from the material at hand that $H$. brooki was not introduced from the Congo.

\section{Explanation of Plates}

Figure 1. Sphaerodactylus macrolepis from St. Croix. A. underside of male, note speckled throat not stopping abruptly at neck. Note speckled abdomen. B. Underside of female. Note marbled chin and spotted underside. C. Female. Note large scapular "mask" and target pattern on head. D. Male. Note diffused pattern on head, small scapular mask and nearly clear dorsum.

Figure 2. A. and B. male S. macrolepis from Culebra. Note black occipital spot on head and speckled throat with abrupt demarcation at neck and clear venter. C. and D. male S. danforthi from Culebra. Note unmarked head, no scapular pattern and clear chin and venter.

Figure 3. A. and B. female S. macrolepis from Culebra. Note target pattern on head, large scapular mask, faintly mottled chin and clear venter. C. and D. female S. macrolepis ? from Culebra. Note very coarse scales, striped head, and very vividly marked throat and chin.

Fig. 4. S. danforthi from Anegada. A. and B. Males. Note clear throat and venter, clear head, small scapular pattern and dotted dorsum and tail. C. and D. Females. Note similarity to females of S. macrolepis from Culebra.

Fig. 5. S. beattyi. A. Type. Adult female. Note fine scales, interocular stripe and occipital dark spot. B. Adult male. Note similarity to female and light " $\mathrm{Y}$ " on sacrum which occurs on all specimens except type. C. Adult female. Note immaculate venter, common to both sexes. D. Immature. Both sexes similar. Note striped head and light "Y" on sacrum.

Fig. 6. Ameva polops Cope. After a painting by Harry Beatty. 


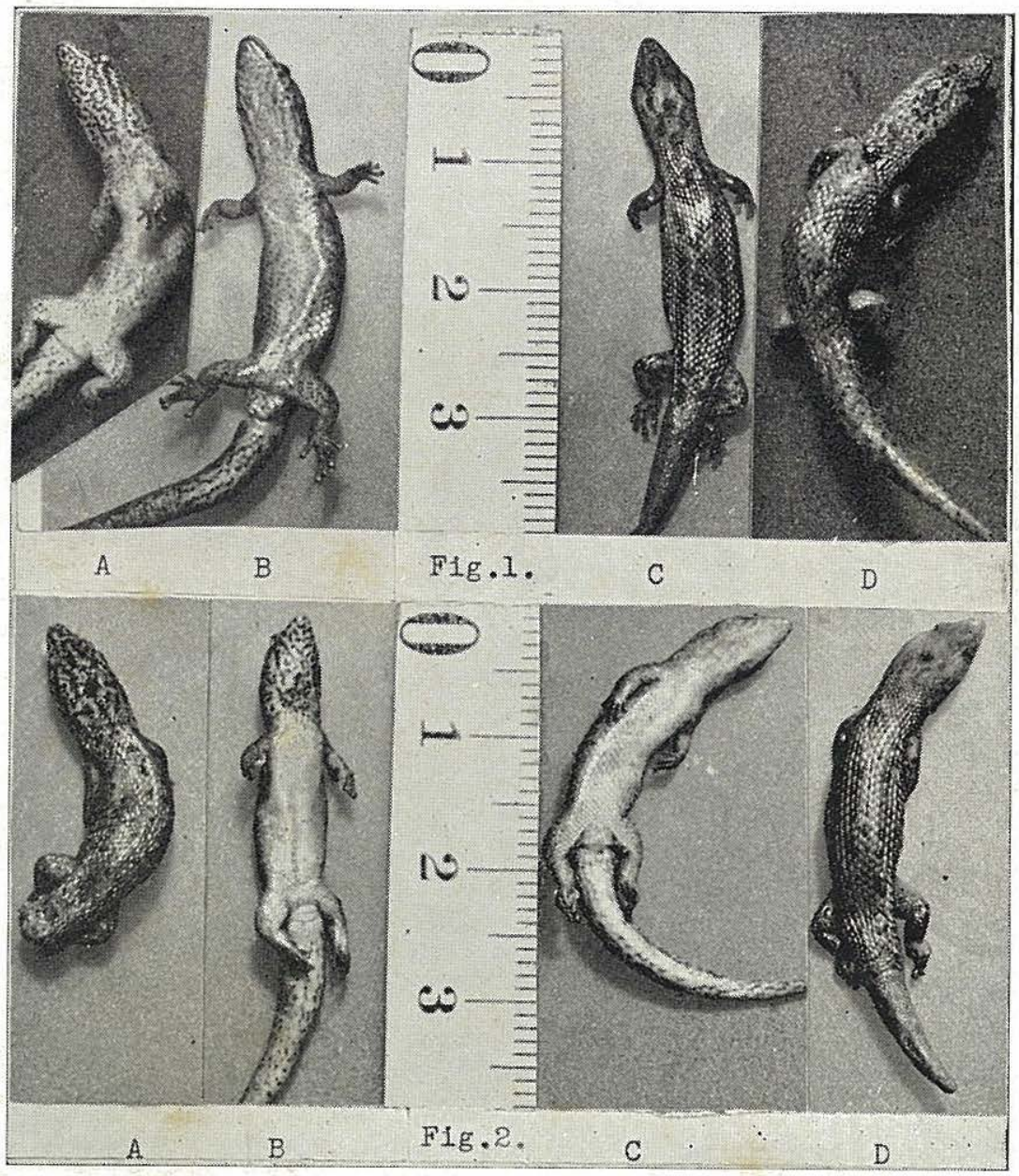




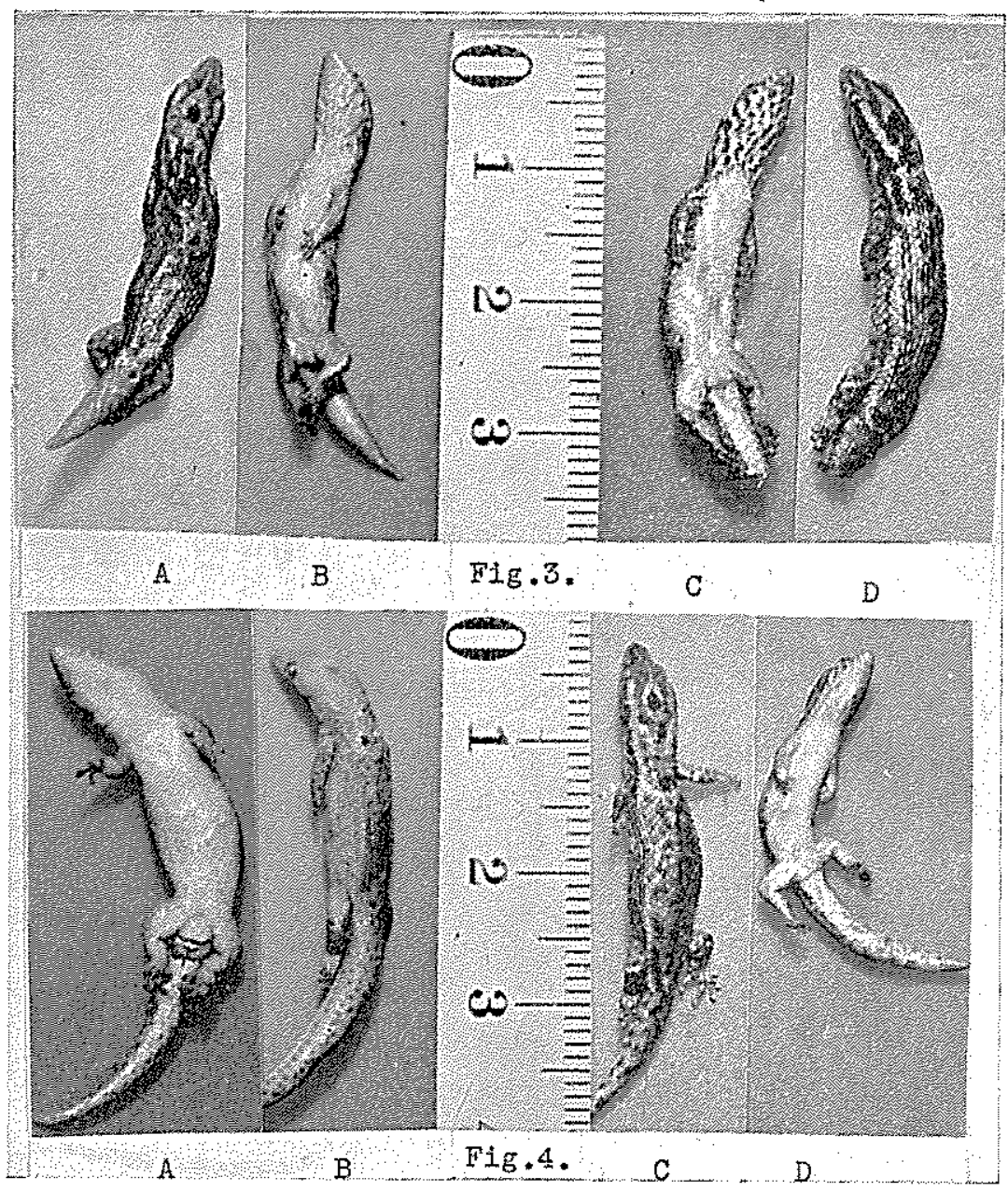




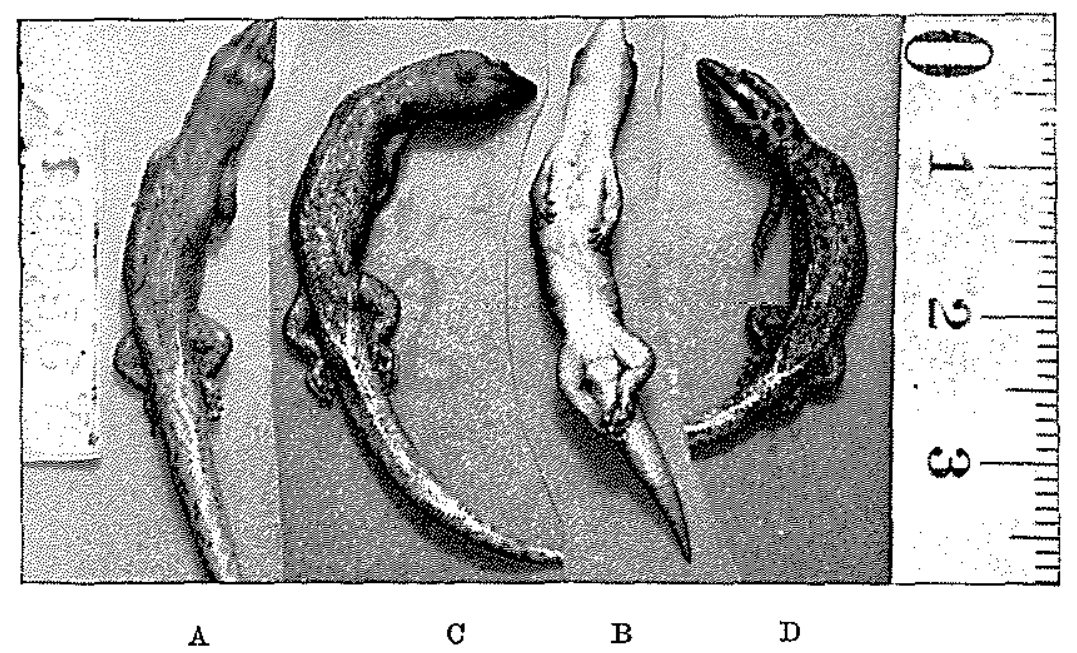




$$
A
$$

